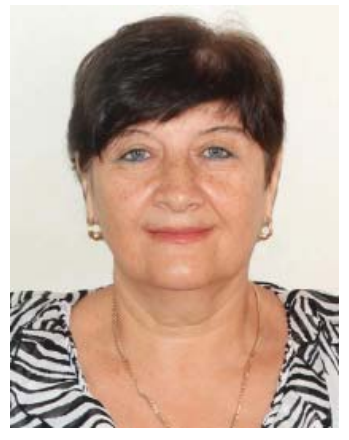

\author{
L. Aladashvili, M. Arabuli, N. Tchlikadze \\ Tbilisi State Medical University
}

\title{
Age-related Changes of Diameter and Deformability of Red Blood Cells
}

Introduction. The diameter and deformability of red blood cells (RBCs) play a very important role in the maintenance of normal blood flow in the microcirculation $[3,4]$. Aspects of RBCs deformability have become increasingly important in various clinical situations $[2$, 7]. However, the precise molecular mechanism of the regulation of RBCs deformability, and, in particular, the mechanism responsible for changes in the membrane properties associated with its elasticity remains to be solved. RBCs deformability has been described based on three physical properties: membrane viscoelastic properties, the internal viscosity and the surface area-to-volume ratio $[1,5]$. Viscoelastic properties of the membrane, as we know, depend greatly on the membrane phospholipids (saturated/non-saturated) and the cholesterol consistence. The change of the concentration of the cholesterol and the saturated lipid acids or the rusty modification of unsaturated phospholipids (oxidation stress) causes the decrease of the deformability of the membrane. The internal viscosity of RBCs depends on the cells' volume and property of hemoglobin. Changing of corpuscular hemoglobin concentration in cases of thalassemias (light globin chains), increasing flexibility of hemoglobin (sickle-cell anemia) induces changes of internal viscosity of RBCs. The membrane properties and thus the deformability of RBCs are largely detailed and considerable information is available regarding the skeleton composition, ultrastructures, proteinto-protein interactions, membrane anchorage, and molecular defects [5].

Nevertheless, such information has not been examined in relation to the overall physiological functions of RBCs such as deformability and cells' volume. The changes of the volume, diameter of erythrocytes should be caused by the abolishment of the osmotic pressure between intra- and extracellular spaces, connected to the membrane ionic channels dysfunction. Along with the changes of the volume of the cells, the hemoglobin concentration in erythrocytes changes, which itself causes the decrease of its internal viscosity and the deformability of the membrane.
The purpose of the research was to study the agerelated changes of diameter and deformability of RBCs in practically healthy volunteers.

Materials and research methods. Morphological and biophysical parameters (diameter, deformability) of RBCs were studied in 50 practically healthy men - volunteers. They were divided into two age groups: adults (22-30 years old, 25), and old people (75-89 years old, 25).

For a morphological research were made smears, which were dyed by Sudan Black according to the method of J. F. A. McManus. Diameter of erythrocytes was measured with the ocular micrometer.

The deformability of erythrocytes was determined with the help of the computer filter-photometer method. The time of the diffusion on the filter paper was determined for this pattern.

Statistic processing of obtained results was conducted according to the program SPSS, version 11.0. Student's t-test was used for analysis of differences between means and a change with a $p<0.05$ was considered statistically significant.

Results. Table 1 shows the indices of the RBCs' diameter of the young and old people. As it is shown, the tendency of the increase in the diameter of the RBCs is seen in aged people, this indicates that the volume of erythrocytes is increased in old people.

Diameter of RBCs in adults and old people

Table 1

\begin{tabular}{|c|c|c|}
\hline Group & $D(\mu \mathrm{m})$ & $p$ \\
\hline Adults (22-30 years old) & $5.8 \pm 0.3$ & \multirow{2}{*}{$<0.01$} \\
\cline { 1 - 2 } Old people (75-89 years old) & $6.6 \pm 0.3$ & \\
\hline
\end{tabular}

Table 2 shows the results of the research of erythrocytes' deformability.

Deformability of RBCs in adults and old people

\begin{tabular}{|c|c|c|}
\hline Group & $\begin{array}{c}\text { Deformability } \\
\text { (percentage\% ?) }\end{array}$ & $p$ \\
\hline Adults (22-30 years old) & $4.2 \pm 0.2$ & \multirow{2}{*}{$<0.01$} \\
\hline Old people (75-89 years old) & $3.3 \pm 0.3$ & \\
\hline
\end{tabular}


The results of the table show that the number of the RBCs that passed the filter paper per time unit in old people is statistically significantly low compared to the young people.

Pathways, which affects properties regulating RBCs deformability and finally leads to the removal of old cells from the circulation by macrophages on a spleen level are described in the literature [6].
Conclusions. The excessive number of large-sized matured (aged) erythrocytes is revealed in the blood of old people. Different rheological characteristics of RBCs in various aged volunteers have as a result the aged-related cardiovascular diseases.

\section{References}

1. Chien S. Red cell deformability and its relevance to blood flow / S. Chien // Ann. Rev. Physiol. - 1987. - Vol. 49. P. $177-192$.

2. Contributions of sickle hemoglobin polymer and cell membranes to impaired filterability / H. Hiruma, C. T. Noguchi, N. Uyesaka [et al.] // Amer. J. Physiol. - 1995. - Vol. 268, N 5, pt. 2. - P.H2003-H2008.

3. Further investigation of red cell deformability with nickel mesh / K. Arai, M. Iino, H. Shio, N. Uyesaka // Biorheology. 1990. - Vol. 27. - P. 47-65.

4. Kaestnera L. Ion channels in the human red blood cell membrane: their further investigation and physiological relevance / L. Kaestnera, I. Bernhardt // Bioelectrochemistry. - 2002. - Vol. 55, N 1-2. - P. 71-74.

5. Mohandas N. Red cell deformability, membrane material properties and shape: regulation by transmembrane, skeletal and cytosolic proteins and lipids / N. Mohandas, J. A. Chasis. // Semin. Hematol. - 1993. - Vol. 30. - P. 171-192.

6. Romero P. J. The role of calcium metabolism in human red blood cell ageing: a proposal / P. J. Romero, E. A. Romero // Blood Cells Mol. Dis. - 1999. - Vol. 25. - P. 9-19.

7. The clinical importance of erythrocyte deformability, a hemorrheolog. Parameter / F. Ch. Mokken, M. Kedaria, Ch. P. Henny [et al.] // Ann. Hematol. - 1992. - Vol. 64. - P. 113-122.

Стаття надійшла до редакції журналу 1 червня 2016 р.

\section{Age-related Changes of Diameter and Deformability of Red Blood Cells}

\section{Aladashvili, M. Arabuli, N. Tchlikadze}

The goal of the research was to study the age-related changes of diameter and deformability of RBCs in practically healthy volunteers. Morphological, biophysical and biochemical parameters of RBCs were studied in 50 practically healthy men (divided in two age groups: adults (22-30 years old), and old people (75-89 years old)). It was concluded that excess number of large-sized matured (aged) erythrocytes is revealed in the blood of old people. RBC ageing is closely related to a progressive decrease in ADP/ATP ratio, which provides disorders of osmotic balance, cells' swelling, activating signal transduction system, which affects properties regulating RBC deformability and finally leads to the removal of old cells from the circulation by macrophages at spleen level. Received results show different rheological characteristics of RBCs in various aged volunteers.

Keywords: erythrocytes, deformability, age peculiarities.

\section{Вікові особливості діаметра та деформабельності еритроцитів}

\section{Л. Аладашвілі, М. Арабулі, Н. Члікадзе}

Вивчено вікові особливості деформабельності еритроцитів у осіб різного віку. Проведено дослідження морфологічних, біофізичних та біохімічних параметрів еритроцитів у 50 практично здорових волонтерів [дві вікові групи: молоді люди (22-30 років), люди похилого віку (75-89 років)]. У літніх людей виявлено надлишок великих (зрілих) еритроцитів, що зумовлено зменшенням співвідношення АДФ/АТФ, порушенням осмотичного балансу, збільшенням об'єму клітин, активацією сигнальних систем, що беруть участь у регулюванні деформабельності еритроцитів. Усе це сприяє виведенню старих еритроцитів із циркуляційного русла за допомогою макрофагів селезінки. Отримані результати свідчать про відмінності реологічних характеристик еритроцитів у осіб різного віку.

Ключові слова: еритроцити, деформабельність, вікові особливості. 